\title{
アスファルト舗装における応用
}

稲 垣 健 三

東亜道路工業株式会社（横浜市南区中村町 5-318）

\section{Application of Surfactants to Asphalt Road-Construction}

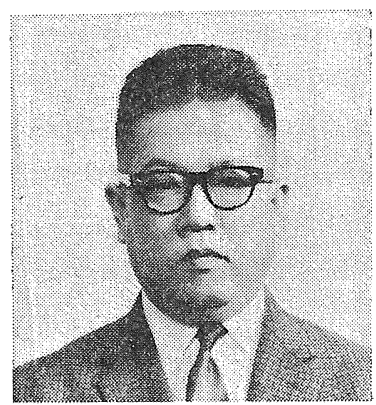

\section{Kenzō INAGAKI}

Tōa Dōro Industry Co. Ltd., Technical Laboratory

(318-5 chome, Nakamura-chō, Minami-ku, Yokohama-shi).

\section{1 はじめに}

近年わが国におけるモータリゼーションの発達は著し く，それに伴う道路舗装が急がれ，数年前までの日本の 道路の悪評は解消されつつ票る。とくに名神高速道路, 東名高速道路を始めとして，国際的な高速道路がどんど ん延びていく反面, 未舗装道路が沢山残されており，こ れらの舗装化が急務になっている。だが道路舗装という ものは非常に費用のかかるものであり（土地買収費など を別にしても，交通量，予算などを考光合わせて，高級 舗装にするか，簡単舗装にするか，あるいは防ジン(塵) 処理的なものにするかが決められる。

道路舗装には大きく分けて 2 通りの方法がある。その 一つはコンクリート舗装であり,もら一つがアスファル 卜舗装である。そして現在わが国の場合，その $95 \% く$ らいまでがアスファルト舗装である。その理由として は,

1) コンクリート舗装の場合，長時間の養生時間を要 し( 1 週間 2 週間)，そのため新設 のときはとむ かく，施工後すぐ交通開放しなければならないオー バーレイ(舗装が痛んできたとき，その上に舗装を カサ上げすること)，打ち直しとして補修用に使用 することができない。

2) 日本のように地盤の悪いところでは, 剛性舖装で あるセメントコンクリート舗装よりも，タワミ性舗 装であるアスファルト赤装の方が適している。

3） セメントコンクリート舗装よりもアスファルト舗 装の方が作業能率が良い。

4）セメントコンクリート舗装は壞れた場合そその上 にオーバーレイができない。舗装が壞れると下のコ ンクリートの小片が動きテコのようになり，上の舗 装体を破壞してしまう。そのため壇れた舗装をいっ たん取り除いた上，打ち直さねばならない。

5）セメントコンクリート舗装は, 気温変化により膨
張，収縮を生ビ，そのため目地を切らねばならず, 舗装の平坦性が損なわれる。 などがあげられる。

さて，そのアスファルト舗装に対して界面活性剤の使 われ方には二通りある。その一つは八ク離防止剤として であり，他の一つはアスファルト乳戍を製造するための 乳化剂としてである。以下この二つについて，とくにア スファルト乳刻のことを中心に述べたいと思う。

\section{2 アスファルト・ハク離防止剤について}

アスファルトは製法により，ストレートアスファル ト,ブローンアスファルト，および溶剤アスファルトに 大別され，また原油の種類により, ナフテン系アスファ ルトとパラフィン系アスファルト，および混合基アスフ アルトとに分類される。そして道路舗装用として使われ るのは，ほとんどストレートアスファルトであり，また 原油事情からナフテン系アスファルトは少なくなりつつ あり，大部分がパラフィン系アスファルトおよび混合基 アスファルトである。

アスファルト舗装の多くは加熱アスファルトコンクリ 一ト舗装であり，とくに高級舗装の表層はすべて加熱ア スファルトコンクリート舗装であるが, アスファルトは とくにパラフィン系のものは無極性であるため, アスフ アルトと石が良く接着せず，骨材面からアスファルトの 被膜がはがれるという現象が生じることがある。とくに 石質の種類, 石の表面のよごれが多いものについて, 地 下水位が高いとか, 排水設備の不備のため舗装体中に水 が存在し，また重交通のため舗装体がもまれた場合，八 ク離はひどく生ずる。アスファルト舗装は一般に $5 \mathrm{~cm}$ 以上の厚みがあり，その表面にかかる荷重は骨材を介し て下部層に分散伝達され,アスファルトはその荷重を分 散伝達しやすい位置に骨材を固定する接着剤としての役 目を果たしている。したがって骨材表面からアスファル ト被膜がハク離すれば,アスファルトは接着郕としての 
役目を失い骨材は交通により動き，荷重を支えることが できなくなり，舗装体は破壊してしまうであろう。

そこで, アスファルトに極性物質を添加し, その八ク 離防止性を向上させようという試みがなされてきた。ア ルキルアミンまたはその誘導体がハク離防止剂として効 果があるとされている ${ }^{65)}$

アスファルト・ハク離防止剤の効果はアスファルトの 骨材表面への付着張力の増大にあるといわれている。す なわち, 水の骨材表面への付着張力よりもアスファルト の骨材表面への付着張力の方が大きければ，たとえ水が 存在しても八ク離は生じないわけである。

さて，アスファルト・八ク離防止剤が効果があるかな いかを土木的に室内試験で行なら方法としては，(1) マ ーシャル安定度試験(非水浸叔よび水浸による)，(2) ア スファルト被膜のハク離試験法（アスファルト舗装要綱 付録改訂 b. アスファルト舗装要綱付録 4-7) などが通常 行なわれている方法である。

しかし, これらの室内試験で良好だったものが, 実際 に現場で使用した場合必ずしも好結果を得るとは限ら ずほほかにもっとよい試験方法がないから，仕方なしに 行なっているのが実情である。

市販されている数種のアスファルト・ハク離防止剂に ついて当社で試験を行なった結果を一部記す。

\section{試験内容}

1. アスフォルト………クエート原油使用 $80 / 100$

2. 石質………………石灰岩, 硬質砂岩

3. 試験法……………⑴静的ハク離試験方法（アスフォル 卜舗装要綱付録 b)

(2)マーシャル安定度 : $60^{\circ} \mathrm{C}$

$30 \mathrm{~min}, 60^{\circ} \mathrm{C} 12 \mathrm{hr}$

(3)ウエット，トラックアブレージョ ン試験

4. 添加量

全種ともアスファルトに対し $0.3 \%$

表-1 静的ハク離試験結果

\begin{tabular}{c|c|c}
\hline ハク離防止剂種類 & ケイ石質岩(\%) & 石灰質岩(\%) \\
\hline 0 & 8.1 & 6.0 \\
A & 0.0 & 0.0 \\
B & 0.0 & 2.0 \\
C & 0.0 & 1.0 \\
D & 3.0 & 1.0 \\
\hline
\end{tabular}

表-2 マーシャル安定度 $\left(60^{\circ} \mathrm{C} 30 \mathrm{~min}\right.$ 浸水)

\begin{tabular}{c|c|c|r|c}
\hline 石 質 & 種類 & 密度 $\left(\mathrm{gr} / \mathrm{cm}^{3}\right)$ & 安定度 $(\mathrm{kg})$ & $\begin{array}{c}\text { フ므-值 } \\
(1 / 100 \mathrm{~cm})\end{array}$ \\
\hline ケイ石質岩 & 0 & 2,332 & 1,019 & 44.1 \\
& A & 2,323 & 630 & 35.5 \\
& B & 2,320 & 809 & 27.9 \\
& C & 2,341 & 1,042 & 29.3 \\
& D & 2,340 & 1,073 & 27.3
\end{tabular}

\begin{tabular}{l|c|r|r|r}
\hline 石灰質岩 & 0 & 2,321 & 910 & 25.5 \\
& $\mathrm{~A}$ & 2,383 & 984 & 22.6 \\
& $\mathrm{~B}$ & 2,375 & 877 & 22.8 \\
& $\mathrm{C}$ & 2,437 & 1,369 & 33.0 \\
& $\mathrm{D}$ & 2,392 & 1,191 & 30.5 \\
\hline
\end{tabular}

注） 5 号 $18.6 \%$ アスフォルト 7.0 6 号 $18.6 \%$

配合

7 号 $16.3 \%$ 混合温度 $130 \sim 140^{\circ} \mathrm{C}$

砂 $33.0 \%$ 突き固め温度 $110 \sim 120^{\circ} \mathrm{C}$

石粉 $6.5 \%$

表-3 マーシャル安定度 $\left(60^{\circ} \mathrm{C} 12 \mathrm{hr}\right.$ 浸水 $)$

\begin{tabular}{c|c|c|c|c}
\hline 石 質 & 種類 & 密 度 $\left(\mathrm{g} / \mathrm{cm}^{8}\right)$ & 安定度 $(\mathrm{kg})$ & $\begin{array}{c}\text { フロ一值 } \\
(1 / 100 \mathrm{~cm})\end{array}$ \\
\hline ケイ石質岩 & 0 & 2,360 & 813 & 27.9 \\
& $\mathrm{~A}$ & 2,335 & 484 & 35.5 \\
& $\mathrm{~B}$ & 2,341 & 506 & 30.5 \\
& $\mathrm{C}$ & 2,319 & 532 & 24.2 \\
& $\mathrm{D}$ & 2,328 & 584 & 33.0 \\
\hline 石灰質岩 & 0 & 2,418 & 746 & 43.2 \\
& $\mathrm{~A}$ & 2,412 & 810 & 45.7 \\
& $\mathrm{~B}$ & 2,390 & 498 & 40.6 \\
& $\mathrm{C}$ & 2,397 & 813 & 45.7 \\
& $\mathrm{D}$ & 2,414 & 897 & 41.6 \\
\hline
\end{tabular}

注）試料は 表-2 のものと同じものを作成使用

表-4 ウットトラックアブレージョン試験

\begin{tabular}{|c|c|c|c|}
\hline 種 & 類 & ケイ石質岩（\%） & 石灰質岩 (\%) \\
\hline & & 3 & 15 \\
\hline & & 4 & 15 \\
\hline & & 3 & 10 \\
\hline & & 3 & 15 \\
\hline & & 5 & 15 \\
\hline
\end{tabular}

注）試料は 表-2 と同じものを作成使用

上の表からわかるように，アスファルト・八ク離防止 剤を入れたものは静的八ク離試験に効果を示す。とくに 石灰岩の場合に顕著である。マーシャル安定度の場合 は，それほど効果はみられない。むしろケイ石質岩を使 用したときは悪くなっている。ウエットトラックアブレ ーション試験においてはまったく差が見られない。

他の試験結果からみても八ク離試験の結果は確かに八 ク離防止剤を使った方が好結果が得られるようである。 だが実際に現場においてどれほどの効果があるかどらか は不明である。アスファルト混合物の性質はアスファル トの量およびその性質, 骨材の量およびその性質, アス ファルトと骨材の界面の性質の三つに分けられるが，ア スファルトと界面の性質である接着勃果が混合物全体の 性質にどれほどの影響を与えるか不明であり，八ク離防 止剤がアスファルトに悪い影響を与光る場合は接着効果 だけ改良できても意味を持たない。その上実際に施工す るに当たっては，合材の性質ばかりでなく，路床の状態 
路盤の状態，施工の良し悪しなど舗装の寿命に影響する 因子が多く，八ク離防止剤が舗装の寿命を長くするとい う証明は困難である。またアスファルト・ハク離防止剂 はかなり高価なものであり，これを添加することによる コストの上昇する分だけ良質な路盤材料を使ったり，厚 みを増したりするのとどちらが有効であるかということ で説得力に欠ける。これらの点が解明され，はっきりと 八ク離方止剤の有利性が証明されれば, アスファルト・ ハク離防止剤への期待と需要は急速に高まっていくこと であろう。

\section{3 アスファルト乳剤について}

\section{1 アスファルト乳剂の歩み}

アスファルト乳剤がわが国で初めて使われ始めたの は, 大正の終りころ, 当時の東京市が大震災で荒廃した 道路の舖装に使用したのが始まりで, 昭和 3 年東京市の 直営工場においてL型ハレルホモジナイザーを使って乳 剂を製造し始めたのがわが国における乳剂国産化の始ま りである。その後昭和 5,6 年にかけて数社の民間企業で いっせいに企業化し始めた。しかし, 当時アスファルト は，製造技術が恶く，今日のような良好なものは少ない 上に，品質にもむらがあり，アスファルト乳㓣用アスフ アルトとしては不向きであった。また乳化剤む今日のよ らに進歩していなかったので, その種類む限定されてい た。その上，使用する側も乳剤というものに対して知識 や経験が浅く製造と使用両面で多くの支障にぶつかり， 苦労したようである。戦争のため一時中断されたアスフ アルト乳剂も，戦後の立ち直りは早かった。

1951 年 (昭和 26 年) ころ, ヨーロッパにおいて，今 迄の陰イオン乳剤とは異なる陽イオンアスファルト乳剤 が開発された。この新しい乳剂は, 骨材表面へのアスフ アルト被膜の接着性, 八ク離抵抗性があるばかりでな く，陽イオン乳化剤はいままで乳化しにくいといわれて いたパラフィン系アスファルトも良く乳化する。そして 陽イオン系乳化剂の欠点であった高価である点も, 界面 活性剤業界の長足の進歩により廉価に求められるように なった。その他，原油事情がナフテン系のものが少なく なり，パラフィン系のものが多くなってきたなども，急 速に陽イオンアスファルト乳郕が延びていった原因の一 つであろう。1957 年 (昭和 32 年), アメリカンビチュ マルス社により米国に紹介された陽イオン乳剤は，その 後まもなくわが国にも紹介され，1959 年 (昭和 34 年) に商品化され発売された。これらと相まって, 製造技術 と施工技術の発達により, 忘用面がしだいに拡大され， 乳剤の種類も増えていった。わが国のアスファルト乳剤 は, 大部分が道路舗装用であり, 防水用, 接着用, セメ ント養生用, 植物養生用, 法面保護用, 競技場などの弾 力性舗装などはまだまだ需要は少ない。しかし，これら
の中には，着実に延びているものもあり，その内大きな 需要を見込むものと思われる。

\section{2 アスファルトの使用法}

アスファルトを使用しようとするとき，まず半固体状 をなしているアスファルトを取り扱いやすいようにしな ければならない。その方法としてつぎの三つがある。

1）加熱溶解：アスファルトを $120 \sim 180^{\circ} \mathrm{C}$ に加熱し て流動性を与え，撒布または混合を行なう。

2）カットバック：溶剤によりアスファルトを溶解さ せ，液状にして撒布または混合に使用する。

3）乳化:アスファルト乳剤の場合は，一般に水を分 散相とした $\mathrm{O} / \mathrm{W}$ 型エマルションにする。

1)に挍いて，加熱アスファルトコンクリートの場合は 大きな設備が必要であり，また煙，粉ジンなどのため， 住宅地の側には設置できず，勢い舗設現場まで合材や長 時間運搬しなければならなくなる。そのため，大規模な 工事には良いが小規模の工事には割高となってしまう。 またストレートアスファルトの撒布は現場でアスファル 卜を溶解するのに非常に時間がかかり，温度管理もうま へいかず，撒布も均一に設計量だけきちんとまくのはな かなかむずかしい。

2)の場合は，火災の危険や臭気があり，また溶剤が完 全に飛んでセットが良くなるまでにかなり時間が要す る。

3)アスファルト乳剤は，スプレーヤーかミキサーそれ に小さなローラーのような簡単な機械があ机ば良く, 臭 気もなく，セットする時間も早くてとくにむずかしい技 術も必要としない。このような利点が買われて，わが国 の簡易舗装の多くにこの乳㸞が使われてきた。そしてこ こ数年来, 工法，機械の改良とわが国の未舗装率の高い ことも相まって，急速に乳剤需要が伸びっつある。その 上最近では，乳剂は簡易舗装ばかりでなく，高級舗装の 上層路盤または基層にまで使われ始めた。今後も道路整 備事業とともにアスファルト乳剂も発達していくことで 㐫万ら。

\section{3 アスファルト乳剂の種類について}

わが国では,JIS が石油アスファルト乳片として, 種類 品質, 試験法を規定している。当社におけるアスファル 卜乳剂を種類別，用途別に分類すると，下のようになる。

1）クレータイプ乳凧

2)

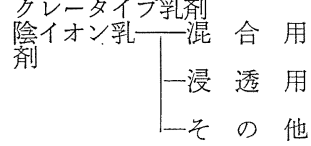

3)

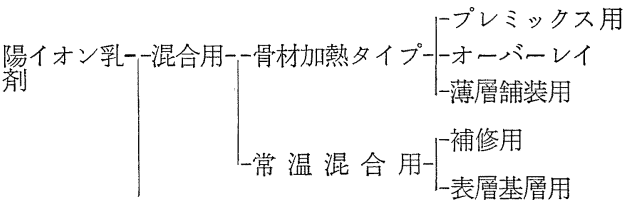




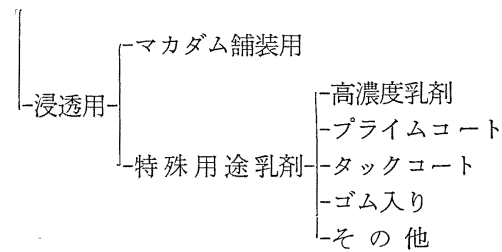

これについて少し述べると，

クレータイプ乳剤：これは乳化剂として，ベントナイ 下, 粘度, 石粉など水に不溶性の鉱物質を中心として, アスファルトを乳化させたものである。ただ，鈗物質だ けでは乳化が不充分なので, 数種の界面活性剤を入れ る。このものは電解質に強く, 混合安定性はあるが粘度 が高く, ホモジナイザーまたはコロイドミルによる量産 ができず，接着性なども悪いので，道路舗装用としては 使われていない。

陰イオン混合用乳剤：セメントと混合しても破壊しな いなぞの特性はあるが，他の性質が陽イオン混合用に及 ばないので，一部の特殊用途を除いて現在ではほとんど 生産されていない。最近欧米で行なわれているスラリー シールにはこの型のものがある。

陰イオン浸透用：マカダム舗装用のものは, JIS. PA1 (冬期の場合は PA-2). PA-3, PA-4 の三つの規格に 合うように作られている。乳剤としての諸性質はいずれ も陽イオン乳剂に劣るがコストが安いため, 多少生産さ れている。

その他陰イオン乳剤：その他の陰イオン乳剂には植物 養生用, 石高ボード防水用, 接着用特殊混合用などがあ る。この特殊用は, 一般道路舗装ではなく競技場, 公園 などのカラー舗装に使用されるものである。

陽イオン常温混合用: 常温混合用の中に 3 種ある。第 一は表層, 基層, 上層路盤など厚みのある舗装に使用す るもので，JIS. MK 1 3 はこの中にはいる。ただし，実 際には気温，砕石の種類，配合，混合してから施工する までの時間などの施工条件に合致させるためには，JIS の 3 種類では閒に合わず, 当社においては約 30 種類の ものを製造している。つぎに登油，ガソリンなどを混 ぜアアスファルト合材に柔軟性と粘着性扝よび貯蔵性を 持たせたものが補修混合用乳剤である。穴埋め, クラッ クのはいった舗装のオーバーレイなどに用いられる。

陽イオン混合用加熱タイプ：これは常温混合式と異な

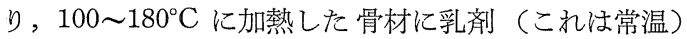
を入れて混合する。混合は普通, アスファルトプラント を利用している。骨材を加熱するため普通の常温混合式 工法に比べ手間がかかるが，その代わり加熱アスファル トコンクリートのような混合物になる。このものの特徴 は,

a） 油量の添加量，アスファルトのグレードなどによ リ, タワミ性, 安定度, 硬化性など混合物の性質を調節
でき，パッチング用，オーバーレイ用，薄層舗装など使 用者の要望どうりのものを製造することができる。 b) 混合時に乳剂中の水分が加熱骨材に接触したとき水蒸気 となり,フォームドアスファルトに似た作用をしてスム 一ズな混合性を示す。c）乳剤中の界面活性剂がハク離 防止剤として働き，骨材との付着性を良好にするなどの 特徴を持つ。

陽イオン浸透用（マカダム舗装用）：乳剤中最も多量 に作られているもので, JIS. PK-1 (冬期は PK-2) PK $-3, \mathrm{PK}-4$ の規格に合うように作られている。用途は陰 イオン浸透用と同じである。陰イオン乳剤に比べ，骨材 に対する接着性，対八ク離性が良い，分解時間が速い， 乳剂の安定性が良い，パラフィン系アスファルトを使 用したものでも良い乳剂が得られる，などの長所があ る。

陽イオン浸透用，特殊用途乳剤高濃度乳剂一通常の陽 イオン浸透用乳剤は，アスファルト含有量が 55 ア 56\% に製造されているが，このものは 60 69\% に作られる。 アスファルト含有量を多くすれば，水分がそれだけ少な いから分解が早く，流失などの口スもなく，接着性も良 い。そのためこの種の乳剤が徐々に増えつつある。ただ し，68〜 69\%くらいの高濃度にすると常温撒布ができ ず，加熱が必要となる。プライムコート用乳剤-JIS 規 格通りの乳剤ではあまり浸透性が良くないので，溶剤を 添加したり，アスファルト含有量を減らしたりして浸透 性を改良したものである。そのほか基層と表層との接着 性を高めるため，用いるタックコートなどがある。

\section{4 乳 化 剂}

アスファルトの乳化については，陽イオン界面活性剂 を初め陰イオン界面活性剤, 非イオン界面活性剤, お上 び両性界面活性剂とほとんどの界面活性剂がその用途に 応じ利用の対象となる。また安定性保護剤的な役目を 持つものとしてパルプ廃液からとれるリグニン，ゼラチ ン，メチルセルロース, ポリビニルアルコールなども使 用されている。ここでは紙面のつごらもあり，現在最も 多く用いられている陽イオン界面活性剂を中心に非イオ ン界面活性剤㧍よび陰イオン界面活性剂について簡単に ふれる。

陽イオン界面活性剂

Amine type

$$
\mathrm{R}-\mathrm{N}<_{\mathrm{R}^{\prime \prime}} \mathrm{R}^{\prime} \quad\left(\mathrm{R}, \mathrm{R}^{\prime}, \mathrm{R}^{\prime \prime} ; \mathrm{H} \text { またはアルキル基}\right)^{1) \sim 3}
$$

$\mathrm{H}$

$\mathrm{R}-\stackrel{\mathrm{N}}{\mathrm{N}}-\mathrm{CH}_{2}-\mathrm{CH}_{2}-\mathrm{CH}_{2}-\mathrm{NH}_{2}$ (R; アルキル基)4) 11)

Quaternary salts type

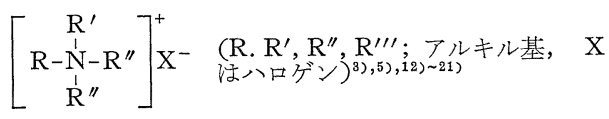


その他

$$
\begin{aligned}
& \mathrm{R}-\mathrm{CONH}\left(\mathrm{C}_{2} \mathrm{H}_{4} \mathrm{NH}\right)_{n} \mathrm{H}
\end{aligned}
$$

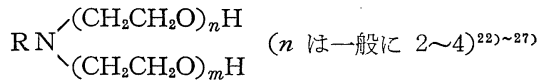

$$
\begin{aligned}
& \mathrm{R}-\mathrm{C} \underset{\backslash \mathrm{N}-\mathrm{CH}_{2}}{\stackrel{\mathrm{N}-\mathrm{CH}_{2}}{\mathrm{C}}} \quad(\text { イミダゾリン型 })^{13), 28), 29} \\
& \mathrm{CH}_{2} \mathrm{CH}_{2} \mathrm{OH}
\end{aligned}
$$

陰イオン界面活性剂

$\mathrm{RCOONa}^{302 \sim 39}$

$\left.\mathrm{RSO}_{3} \mathrm{Na}^{34}, 388,40>\sim 47\right)$

$\mathrm{ROSO}_{3} \mathrm{Na}^{48,483}$

$\mathrm{CH}_{2} \mathrm{OOCR}{ }^{39}$

$\mathrm{CH}_{2} \mathrm{OH}$

$\mathrm{CH}_{2} \mathrm{OSO}_{3} \mathrm{Na}$

非イオン界面活性剂

$\left.\mathrm{RO}-\left(\mathrm{CH}_{2} \mathrm{CH}_{2} \mathrm{O}\right)_{n}-\mathrm{H}^{50}\right)$

$\mathrm{R}-\langle\overline{-}\rangle-0-\left(\mathrm{CH}_{2} \mathrm{CH}_{2} \mathrm{O}\right)_{n} \mathrm{H}^{51) \sim 54}$

$\operatorname{RCON}\left\langle\begin{array}{l}\left(\mathrm{CH}_{2} \mathrm{CH}_{2} \mathrm{O}\right)_{n} \mathrm{H}^{54), 55)} \\ \left(\mathrm{CH}_{2} \mathrm{CH}_{2} \mathrm{O}\right)_{n} \mathrm{H}\end{array}\right.$

$\mathrm{RCOO}\left(\mathrm{CH}_{2} \mathrm{CH}_{2} \mathrm{O}\right)_{n} \mathrm{H}^{56)}$

$\mathrm{RS}\left(\mathrm{CH}_{2} \mathrm{CH}_{2} \mathrm{O}\right)_{n} \mathrm{H}^{57)}$

アミン系の界面活性剤は効果的な界面活性剂ではある が，それ自身では中性の水に溶けにくく，酶酸および塩 酸を用いて酸性側で溶解して使用する。この場合, 塩酸 で $\mathrm{pH}=2$, 酶酸で $\mathrm{pH}=4.5 \sim 5.5$ 前後が良好なようで ある。エチレンオキシド付加物はそれ自身も乳化力を充 分に満たしているが，コストがやや高くなるため乳化以 外の要素が要求される場合に用いられることが多い。た とえば，混合用乳剤の骨材と乳剤の混合後の分解時間の 遅延などが要求される場合にこの種のものが使用され る。ただし，エチレンオキシドの付加モル数が多くなる と陽イオン性が弱まり，非イオンの持つ欠点（石との付 着性が悪いなど）が現われることがある。非イオン界面 活性剂も陽イオン界面活性剂と併用されているが，特殊 な場合だけに限定されている。とくに，鉱サイが骨材と して用いられる場合，鉱少イがアルカリを溶出するた め，陽イオン界面活性剤のみで乳化された乳剤は，アル カリにより，分解が急速に起こり，舗設する際の作業に 非常な障害となることがある。ゆえにこのような場合非 イオン界面活性剂を合わせて乳化しておくと，エチレン オキシドの水和構造により乳剤の安定化を保てることに なる。これら特殊なものを除くと非イオン界面活性剤は あまり利用されていない。また浸透用乳剤と比べ，混合 用乳剂は極度な安定性を要求されるが，これを満足する には界面活性㓮の親油基の長さがある程度長いことが必 要条件である。つぎに陰イオンおよび陽イオン乳剤につ いてのモデルを示す（図-1，図-2)。

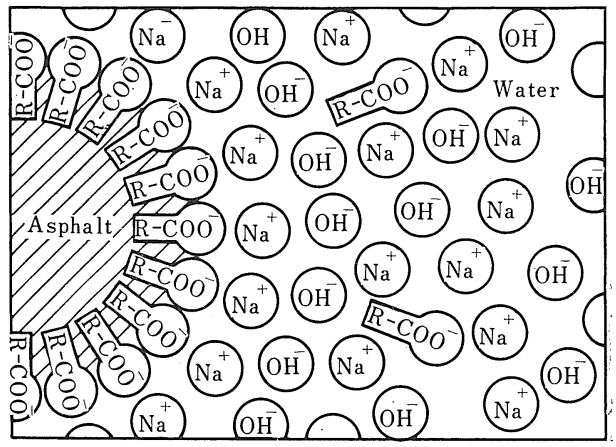

图-1 陰イオン分散粒子

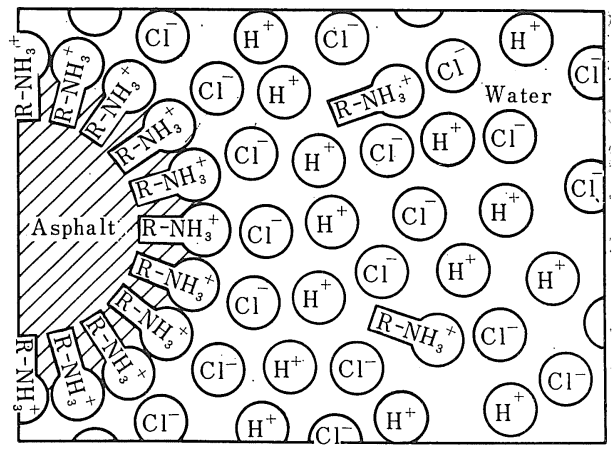

図-2 陽イオン分散䊀子

\section{5 乳 剤 の 諸 性 質}

5.1 粘度: アスファルト乳剂の粘度は, その用途上 かなり高濃度（ $\phi \fallingdotseq 0.4 \sim 0.69 ）$ で使用されること，また 用いる乳化剤およびアスファルトの性質に依存するた め，一般式で表わすことは不可能と思われる。これはア スファルト自身が混合物ゆえ，あまり理論的な議論の対 象に成りにくいことも原因の一つであ万う。しかし，陽 イオン乳剤の乳化安定性と粘度に関しては, 和田, 小池 $ら^{58}$ の貴重な報告がみられる。かれらは粘度について， Eilers ${ }^{59}$ が陰イオンアスファルト乳剂について提案した 分散粒子の集合時に抢ける相互のつめこみの効果を考慮 した粘度式を陽イオンアスファルト乳剂に適用し，ほぼ 一致をみている。しかしながら，この式もアスファルト 乳剤一般に適用するには検討の必要があると思われる。 著者らは，同じアスファルト乳剤でも浸透用と乳化の良 好な混合用乳剂では， $\eta_{r}-\phi$ 曲線が非常に 異なることか ら, $\operatorname{Roscoe}^{60)}$ の式を変形し, 乳化剂拉よびアスファル 卜の性質による係数 $(k)$ の変化を仮定し，つぎのような 適用を試みた。

$$
\eta_{r}^{-2 / 5}=1-k \phi
$$

$\phi:$ volume fraction

$\eta_{r}{ }^{-2 / 5}-\phi$ プロットは，一般の浸透用乳剤の場合直線関倸 を示すが，乳化の良好なものほど， $k$ は大きな值を示 す。しかしながら，混合用乳剤のように数種の乳化剤を 
用い，また乳剂使用量も多い(乳剂が良く分散粒子の径 も浸透用乳剤と比べてかなり小さい）ものは，直線から のずれを示す。この場合は，分散粒子間の相互作用を考 慮し，二次の項を加えて補正して適用した。

$$
\eta_{r}{ }^{-2 / 5}=1-k \phi+a \phi^{2}
$$

しかしながら，このような取扱も乳剤によっては完全な 二次曲線ではない場合も多く, 問題がある。いずれにせ よ, 係数 $k, a, \phi$ はの増加による増粘性の尺度となり る。一般には, $\phi$ 一定の場合, 浸透用乳剂の方が粘度が 低く，構造粘性も顕著でない。

5.2 粒度分布: アスファルト乳剂の粒度分布は, 一 般のエマルションと同様に，乳化当初はかなりシャープ なガウス分布を示すが, 図-1 に示されるように, 径時 とともに分布はブロードとなり, 平均粒径は大きくな る。

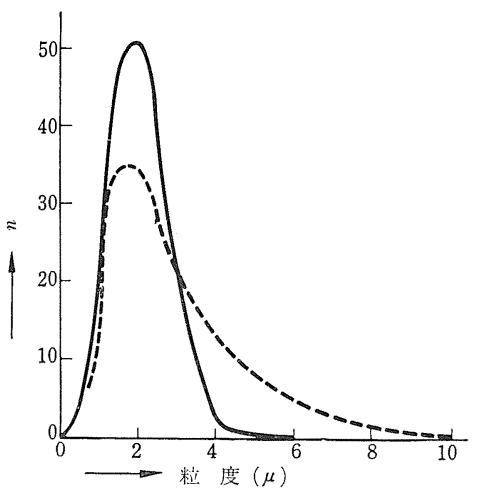

図-3 粒度分布のグラフ

粒度の測定は，顕微鏡による写真撮影が多く利用され ているが，正確な分布を知るためには 2000 個以上の粒 子を測定する必要がある ${ }^{61)}$ 。図-2 に, 混合用乳剤の写 真を示す。一般に粒子が微細なほど安定性が良いようで ある。

5.3 砕石（骨材）との付着性：アスファルト乳剤の 最も指摘される特徴は, ぬれている骨材にも付着し, 砕 石表面において分散粒子が水と置換することにより，バ インダーとしての効果を示すことである。この効果はと くに, 陽イオン性乳剤のシリカ系砕石に対するものが顕 著であるといえる。一方，カルシウム系碎石に対して は，陰イオン乳剤が良好な付着性を示すとされている。 これらについて, Mentens とWright ${ }^{62)}$ は,つぎに示 されるモデルを提案している。

すなわち，砕石表面から水が完全に脱離（分解）し， 除外されると, 接着効果が増大し, 良好な舗装材とな る。そのほか, 石質や考慮した分解のメカニズムについ ては，Gestel ${ }^{63)}$ らの議論もある。

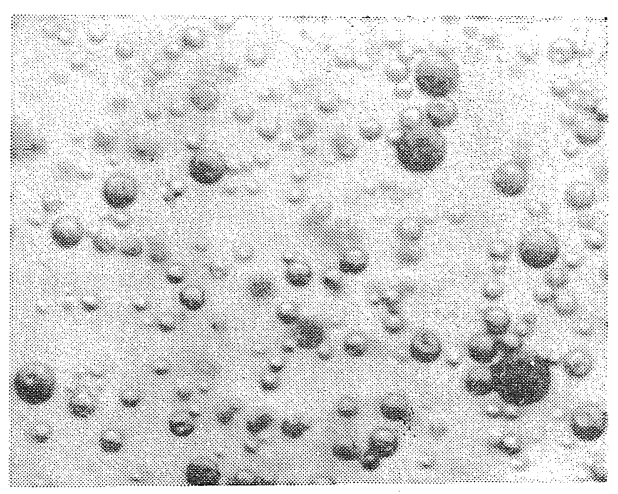

図-4 アスファルト乳戍の顕微鏡写真

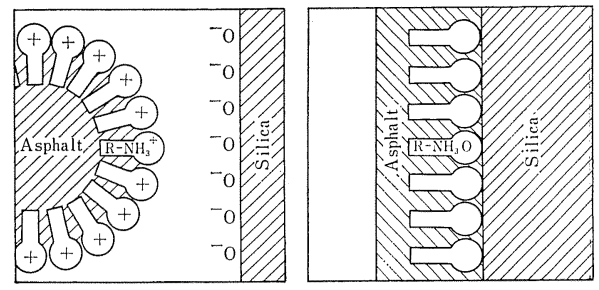

図-5 シリカ表面に対する陽イオン粒子の作用

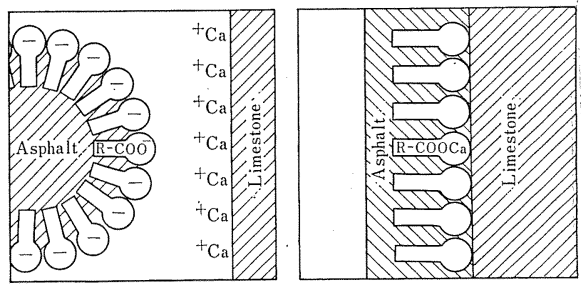

図-6 カルシウム表面に対する㓌イオン粒子の作用

\section{6 アスファルト乳剤によるおもな工法}

6.1 浸透式工法：この工法は，乳郕を用いて簡易舗 装の表層に用いられるもので，粒度の異なる砕石を粒度 別に施工厚に応じて何層かに仕上げるものである。つぎ にその一例を示すが詳しくは簡易舗装要綱 ${ }^{(4)}$ に定められ ている。

図からも明らかなよらに，乳剤を撒布後ただちに骨材 を敷きならし，ローラーにて転圧する操作の繰返しによ るものである。したがって, 浸透用乳剤は, 貯蔵安定性 と撒布性（ポンピング）预よび分解が早いことが望まれ る。

6.2 常温混合式工法: この工法は, 中央混合法と路 上混合法の二つに大きく分けられ，中央混合法はつぎに 示すよらな固定されたプラントのミキサー(パッグミル と呼ばれる) に抒いて, 粒度を調製された骨材に対し約 $7 \sim 8 \%$ の混合用乳剤を添加し混合したもの（合材）を， ダンプカーなどで現場に運搬し，舗設する。 


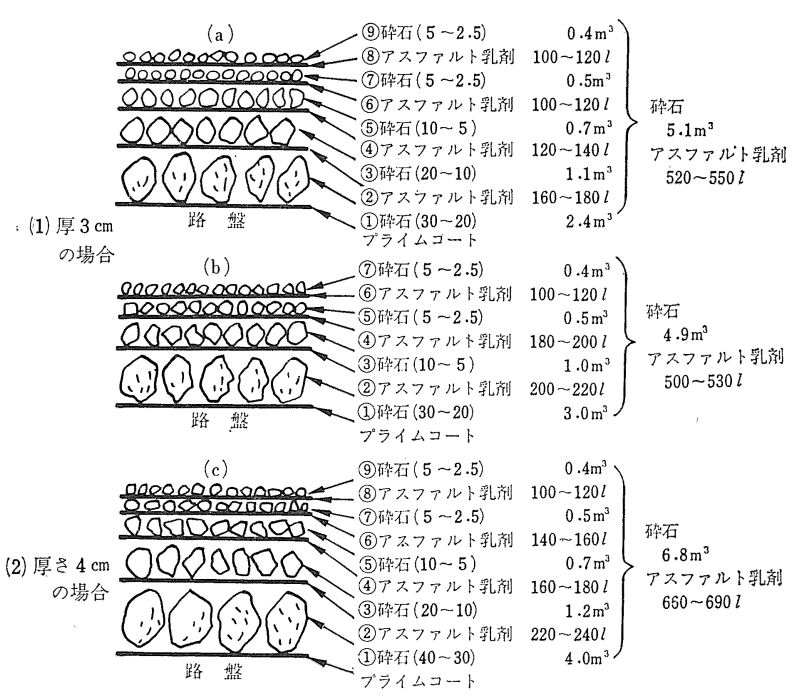

図-7 アスファルト乳剤による浸透式工法の設計例 $\left(100 \mathrm{~cm}^{2}\right.$ 当たり)

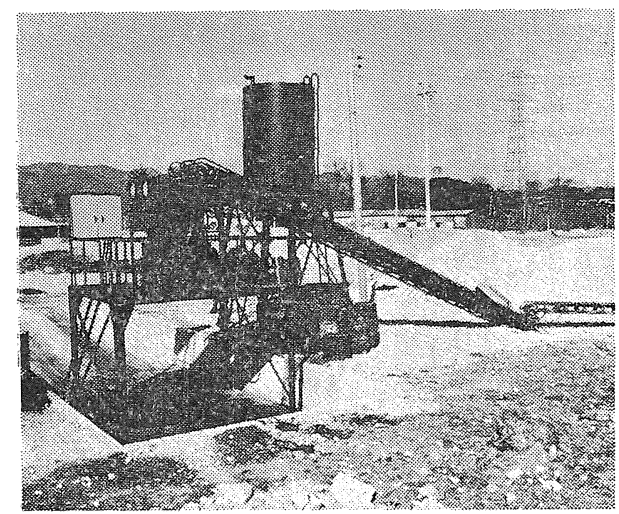

図-8 中央混合プラント

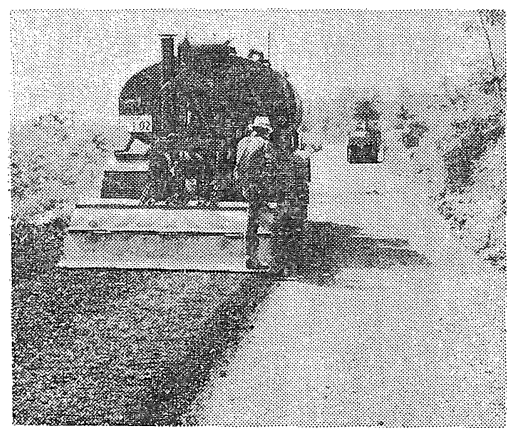

図-9 スタビライザーによる工事

舖設は，合材を敷均しローラー転圧を行なう。一方， 路上混合法は，舗装する路上にあらかじめ骨材を敷均 し，その上をつぎに示されるスタビライザーといわれる 機械（乳剤を撒布しながら，路上で混合を行なう）によ り混合するものである。
これは施工能率の高い工法であり，最近急に延 びつつある工法である。前述したように，この混 合用乳剤は機械的に骨材と混合するゆえ，この混 合に耐えうるような充分な安定性が要求されるこ とや，石質にもかなり左右されるため，浸透用と 比較するとかなり高度な技術が要求される製品で ある。そのほかに種々の工法があるが，ここでは 省略する。

\section{7 おりに}

以上のように，アスファルトに対する界面活性 剤の利用は多岐に及ぶが，アスファルトの用途 上，理論的な議論および微視的な考察はあまりな されていないのが現状である。しかしながら，ア スファルト乳剂はあくまでも物理化学的プロセス により製造されるものゆえ，むっと基礎的な研究 が望まれる。最近国外において注目されているス ラリーシールや，八ク離防止剂などが，国内でも 実用的段階にはいれば，土木材料に対する界面活性㓮の 重用性もさらに高まるであろう。

(昭和 44 年 5 月 17 日受理)

\section{文献}

1) Shell Development Co. U.S., 2, 706, 688 (1955)

2) Standard Oil Co. U.S., 2, 780, 557 (1957)

3）和田, 小池: 油化学, 16 (1), 23-29 (1967); 高麗, 芝 浦工大研報 [14] 35-40 (1966)

4) Esso Standard Societe Anon. francaise, Brit., 792, 648 (1958)

5) A.V. Bernshtein, S.V. Nashivanko, Avtom. Dorogi 24, (7), 16 (1961)

6) Armour and Co., Brit., 1,054,164 (1967)

7) Institut Francais du Petrole des Carburants et Lubrifiants, Fr., 1,475,628 (1967)

8) Chevron Research Co., U.S., 3,340,203 (1967)

9) Phillips Petroreum Co., U.S., 3,389,090 (1968)

10) Societe Chemique, Routiere et d'Enter Prise Generale (S.C.R.E.G.) Fr., 1,479, 444 (1967)

11）日漇化学工業株式会社, 日本特許公告, 昭 39-19,460

12) Shell Development Co., U.S., 2,393,573 (1946)

13) California Research Corp., 3,050,468 (1962)

14) Herbert Kleinert Horst Luckau and Alfred Barsnick. Ger. 34,178 (1964); 35,622 (1965)

15) Merton J. Bargfeldt., U.S., 3,220,953 (1965)

16) Phillips Petroleum Co., U.S., 3,276,886 (1966)

17) Taroslav Buchta, Czech., 120,252 (1966)

18）アーマー社 (米国), 日本特許公告, 昭37-56,127

19）アーマー社 (米国), 日本特許公告, 昭 37-58,542

20）インターナショナル，ビチューメン（米国），日本特許公 告, 昭 39-19378

21）アーマー社 (米国), 日本特許公告, 昭 42-26,762

22) California Research Corp. U.S., 3,062,829 (1962)

23) California Research Corp. U.S., 3,097,174 (1963)

24) Imperial Chemical Industries Ltd., Brit., 914,775 (1963)

25) California Research Corp., U.S., 3,096,292 (1963) 
26) Esso Research and Engineering Co., U.S., 3,207,594 (1965)

27) Zjednoezenie Przemyslu Izolacji Budowlanej (Zaklad Badan i Dowiadczen) (by Romuald Bogoczek,) Pol., 53,905 (1967)

28) Abh. Deut. Akad. Wiss. Berlin, Kl. chem., Geol. Biol. (1966) (6), 491 501

29）インターナショナル，ビチューメン（米国），日本特許公 告, 昭 39-19377

30) Union Oil Co. of Calif., U.S., 2,318,932

31) E.R. Hatt, W.R. Peard, J. Soc. Chem. Ind., 64, 243-53 (1945)

32) International Bitumen Emulsion Ltd., Brit., 577,468 (1946)

33) Shell Development Co., U.S., 2,550,481 (1951)

34) Kerr-McGee Oil Industries Ine., U.S., 3,036,015 (1962)

35) M. Gerasimov, D. Ruschev, Kr. Raikov, L. Branyakov, Godishnik Khim-Tekhol. Inst., 8 (1), 183-203 (1961)

36) Axel O. Bolm (Dommarks Tek. Hojskole, Copenhagen) Finska Kemist Samfundlt Medd., 72 (4), 196-201 (1963)

37) S.V. Egorov, A.V. Bernshtein, E.M. Nashivanko U.S.S.R., 171,307 (1965)

38) Ciupka, Ignacy Lipp. Joachim (Inst. Chem. Przerobki Wegla, Zabrze, Poland) Koks. Smola. Gaz (Poland) 13 (5), 134-138 (1968)

39) Uwe Jens Moeller (Esso A.G., Forschungslab., Hamburg-Harburg, Ger.) Bitumen, Teere, Asphalts, Peche, 19 (1), 3-9 (1968)

40) Atlantic Refining Co., U.S., 2,472,583 (1949)

41) Azienda Nazionable Idrogenazione Combustibili (A.
N.I.C), Ital., 420,771 (1947)

42) Lubri-Zol. Corp., U.S., 2,503,246 (1950)

43) Azienda Nazionable Idrogenazione Combustibili, Ital., 443, 199 (1948)

44) America Bitumuls \& Asphalt Co., U.S., 2,585,336 (1952)

45) Asphalt Specialitis Co., U.S., 2,579,652, (1951)

46) A.G. Ruetgerswerke (by Wolfgang Malchow), Ger., 1,124,416 (1962)

47) State Automotive-Highway Scientific Research Institute, U.S.S.R, 206,375 (1966)

48）昆布谷, 日本特許, 209,365 (1954)

49) 岡翠, 日本特許公告, 昭 $42-14,640$

50）木村木，日本特許公告， 205,484 (1954)

51) Phillips Petroleum Co., Fr., 1,415,875 (1965)

52) phillips Petroleum Co., U.S., 3,345,193 (1967)

53) State Automotive-Highway Scientific Research, U.S. S.R, 206,374 (1967)

54）エッソ，リサーチ Co.，日本特許公告，昭 38-10,182

55）昭和石油 K.K., 日本特許公告, 昭 315,353 (1962)

56) Owens-Corning Fiberglas Co., U.S., 2,701,777 (1955).

57) California Research Corp. U.S., 2,993,002 (1961)

58) 和田ら, 油化学, 16, 23 (1967)

59) P. Becher "Emulsion Theory and Practice" 2-nd Edition p. 61 65, New York, Reinhoed Publishing Corp. (1957)

60) R., Roscoe. Brit. J. Appl. Phys., 3, 267 (1952)

61) P. Sherman "Emulsion Science" London, New York Academy

62) Mertens \& Wright, H.R.B. Proc. 38,386 (1958)

63) Gestel Chemistry and Industry, Feb. 11,221 (1967)

64）日本道路協会 “簡易舗装要綱” p. 20 （昭和 42 年）

65）小池, 和田, 燃料協会誌, 44 (No. 453) 46 (1965), 